\title{
Daar doer in Duitswes
}

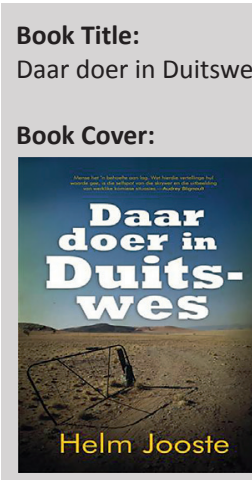

Author:

Helm Jooste

ISBN:

978-1-4853-0064-9

Publisher:

Protea Boekhuis

-

Review title:

Daar doer in Duitswes

Reviewer:

Belia van der Merwe ${ }^{1}$

Affiliation:

${ }^{1}$ Private

Email:

bkjvdm@xsinet.co.za

Postal address:

PO Box 50024, Mafikeng-

South 2791, South Africa

How to cite this book

review:

Van der Merwe, B., 2015,

'Daar doer in Duitswes',

Literator 36(1), Art. \#1163,

2 pages. http://dx.doi.

org/10.4102/lit.v36i1.1163

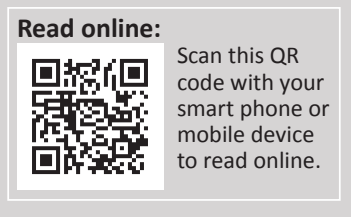

Daar doer in Duitswes (2014) is 'n herdruk van Helm Jooste se bundel biografiese sketse wat in 1989, die skrywer se tagtigste lewensjaar, verskyn het. Dit is opgevolg deur Dinge daar doer (1992) en Verdriet se moses (1996).

Die eerste nege van die 27 sketse in Daar doer in Duitswes dien as agtergrond vir die res van die bundel. Dit speel af in die voormalige Transvaal en bring die leser kortliks op hoogte van hoe die skrywer se ouers ontmoet het, asook van sy kinder- en jeugjare op die Hoëveld.

Na die einde van die Anglo-Boereoorlog keer die skrywer se moeder, as enigste oorlewende van haar gesin, saam met familielede uit die konsentrasiekamp terug na hul afgebrande en verwoeste plaas, Bosmanskraal, in Bethal se distrik. Sy vader, wat as Kaapse rebel aan die oorlog deelgeneem het, word vier jaar later op 'n buurplaas as onderwyser by die Klipkraal-skool aangestel. In 1907, 'n jaar na hul ontmoeting, is Elsa Swart en Hermanus Helm getroud.

Na sy skooljare volg die skrywer in sy pa se voetspore en gaan bekwaam hom as onderwyser. Sy eerste pos is in die destydse Duitswes (soos dit toe nog in die omgangstaal bekend was), waar sy ouers hulle sedert 1927 op 'n plaas in die Mariental-area gevestig het. 'Middel Januarie van die depressiejaar 1931 toe honderde onderwysers in Transvaal werkloos was, het ek die langverwagte telegram ontvang: "Appointed Principal Primary School Westfalen X Please confirm immediately ... Education Windhoek"' (bl. 60). Westfalen, soos dit later sou blyk, is 'n plaas 84 myl noordoos van Mariental, die naaste dorp. Vir die 21-jarige Helm Jooste is dit die begin van 'n verbintenis van baie jare met hierdie uitgestrekte en harde land.

Duits-Suidwes-Afrika het in 1884 'n protektoraat van die Duitse Keiserryk geword en 'n Duitse Kolonie gebly tot aan die einde van die Eerste Wêreldoorlog, waarna die Volkebond aan SuidAfrika ' $n$ mandaat gegee het om die land te bestuur en dit as Suidwes-Afrika bekend geword het. Toe die skrywer daar aanland, was die Duitse invloed nog orals te sien, in plek- en plaasname, in die argitektuur, veral in Windhoek. In kroeë word daar Duitse bier op Duits bestel en later vrolike Duitse liedjies gesing: 'Trink, trink, Brüderlein, trink, / Lass doch die Sorgen zu Haus' (bl. 114).

Die Duitswes-verhale speel almal af in die eerste helfte van die dertigerjare van die vorige eeu en roep 'n lewe in herinnering waarvan min lesers nog regstreeks kennis dra. Dit was die veelbewoë dae van eenvertrekskooltjies op afgeleë plase met kinders van al die standerds en alle ouderdomme in een klas. Mnr. Jooste, die prinsipaal van die Westfalenskool, begin sy eerste dag met 21 leerlinge in agt klasse, sonder 'n skoolgebou of 'n swartbord, en met geen hulpmiddels nie buiten wat hy in 'n petrolkis saamgebring het. 'Uit die petrolkis het ek 'n paar oefeningboeke gehaal waarvan ek die blaaie kon gebruik, enkele potlode wat ek in korterige stukke kon sny, 'n uitveër, 'n gedigteboek van Leipoldt en Loeloeraai van Langenhoven' (bl. 71).

Jooste vertel onderhoudend en met humor van daardie baanbrekersjare. Op die eerste skooldag staan 'n seuntjie eenkant droewig en huil nadat die meneer die fluitjie geblaas het sodat almal in 'n ry moet gaan inval. Op die vraag wat makeer, antwoord hy 'Ek ken nie hierdie speletjie nie, Oom!' Hierop kon die skrywer maar net antwoord: 'Toemaar, boetie, ... omie ken ook nog nie hierdie speletjie nie. Ons is maats' (bl. 74).

Dit is die tyd van bokjolle in die waenhuis en konserte in die skoolgeboutjie; van ongenaakbare skoolinspekteurs en 'n veespekulant wat so oortuigend kon lieg dat 'n mens hom waaragtig glo.

Die dertigerjare was egter ook die tyd van die groot droogte. In 1933 staan die skrywer op die stoep van sy tweede skooltjie, op die plaas Volmoed in die Windhoekdistrik. 'Verstikkende stofstorms jaag voor my oor die vlakte. Warrelwinde draai deur die poort en stofwolke styg

Copyright: (c) 2015. The Authors. Licensee: AOSIS OpenJournals. This work is licensed under the Creative Commons Attribution License. 
hoog, ver anderkant oubaas Dieterle se huis uit' (bl. 97). Toe die uitmergelende droogte aan die begin van Desember 1933 eindelik gebreek word, verander die landswye deurdringende reën Duitswes se droë rivierlope in siedende watermassas wat almal wat dit wil oorsteek, dae lank op die oewer vaskeer.

'n Groot gebeurtenis in die jong onderwyser se lewe is toe hy sy eerste motor in Windhoek gaan koop - 'n Whippet. Dis die motor waarvan hy al jare lank droom: 'Die tweesitplekvuurwa met die kattebak is lank en plat en slank. Afgerond in ivoor met rooi draadspeke en rooi bekleedsel voor en agter. Die voorruit slaan plat, die seilkap slaan af' (bl. 120). Met hierdie motor onderneem die skrywer later 'n lang en moeisame rit oor slegte paaie, deur diep dongas en dik sandstroke na die plaas waar hy vir die nooi van sy hart gaan kuier. Die beskrywing van hul huwelik vorm 'n gepaste sluitstuk vir hierdie Duitswes-kroniek.

Selfspot en humor is belangrike bestanddele van die sketse in hierdie bundel wat tot 'n wye verskeidenheid lesers behoort te spreek. Die treffende illustrasies van T.O. Honiball en Allen Handley, saam met enkele foto's, dra daartoe by om Daar doer in Duitswes 'n baie aangename leeservaring te maak.

\section{Literatuurverwysings}

Jooste, H., 1992, Dinge daar doer, Protea Boekhuis, Pretoria.

Jooste, H., 1996, Verdriet se moses, Protea Boekhuis, Pretoria. 